\title{
PENGEMBANGAN MODUL INTERAKTIF BERBASIS MACROMEDIA FLASH 8 PADA MATERI OPTIK GEOMETRI
}

\author{
Novita Bekti ${ }^{1)}$, Winda Dwi ${ }^{11}$, Nofefta Gola'), Reni Raudhotus ${ }^{1)}$, Lailatul Nuraini ${ }^{1}$, \\ Firdha Kusuma Ayu Anggraeni') \\ ${ }^{1)}$ Pendidikan MIPA/Pendidikan Fisika, Fakultas Keguruan dan IImu Pendidikan, Universitas Jember, Jember, \\ Jawa Timur, Indonesia \\ Corresponding author: Novita Bekti \\ Email : novitabekti84@gmail.com
}

Diterima 28 Januari 2021, Direvisi 03 Maret 2021, Disetujui 08 Maret 2021

\begin{abstract}
ABSTRAK
Teknologi yang berkembang semakin pesat menuntut adanya inovasi dalam dunia pendidikan demi terwujudnya pendidikan yang bermutu. Modul interaktif menjadi salah satu solusi dalam penyampaian materi di setiap pembelajaran. Hal ini dikarenakan tampilan modul yang menarik dan jelas. Tujuan penelitian ini ialah untuk mendeskripsikan respon mahasiswa terhadap pengembangan modul interaktif berbasis macromedia flash 8 pada materi optik geometri. Penelitian ini merupakan penelitian pengembangan dengan menggunakan model pengembangan ADDIE. Modul ini dilengkapi dengan animasi pendukung materi serta soal-soal latihan agar mahasiswa mampu mengasah kemampuannya setelah mempelajari modul tersebut. Subyek penelitian ini ialah mahasiswa mata kuliah Fisika Dasar III di Program Studi Pendidikan Fisika Universitas Jember dengan teknik pengumpulan data menggunakan angket respon. Hasil yang diperoleh dari penyebaran angket respon yakni $79,8 \%$ dengan kategori baik. Sehingga dapat disimpulkan bahwa modul interaktif ini diterima dengan baik oleh mahasiswa dan dapat membantu mahasiswa dalam proses pembelajaran pada materi optik geometri.
\end{abstract}

Kata Kunci : macromedia flash 8; modul interaktif; optik geometri.

\section{ABSTRACT}

Technology that is growing rapidly demands innovation in the world of education for the sake of a quality education. The interactive module is one of the solutions in delivering material in each lesson. This is due to the attractive and clear appearance of the module. The purpose of this study was to describe the student's response to the development of an interactive module based on macromedia flash 8 on geometric optics. This research is a development research using the ADDIE development model. This module is equipped with animation supporting material and practice questions so that students are able to hone their skills after studying the module. The subjects of this study were students of the Basic Physics subject III in the Physics Education Study Program of the University of Jember. The data collection technique used a response questionnaire to collect data. The results obtained from the distribution of response questionnaires were $79,8 \%$ with good categories. So it can be concluded that this interactive module is well received by students and can help students in the learning process on geometric optical material.

Keywords : macromedia flash 8; an interactive module; optical geometry

\section{PENDAHULUAN}

Era milenial menjadi ajang perkembangan teknologi yang semakin pesat terutama di kalangan remaja. Kepiawaian remaja dalam memainkan teknologi tidak perlu diragukan lagi karena saat ini kegiatan remaja banyak memanfaatkan teknologi/internet. Hal ini tentunya menjadi acuan dalam bidang pendidikan untuk mengembangkan sistem pembelajaran yang memanfaatkan teknologi guna menarik minat awal mahasiswa dalam belajar. Banyak mata kuliah yang menjadi pikiran atau beban mahasiswa. Hal ini dikarenakan konsep dari suatu materi yang abstrak hingga minimnya penjelasan dari materi tersebut ataupun kata-kata yang kurang bisa dipahami oleh mahasiswa. Kemasan penyampaian materi pembelajaran yang menarik tentunya akan membangunkan keinginan mahasiswa dalam belajar sehingga mahasiswa lebih mudah dalam memahami materi.

Masalah terbesar dalam dunia pendidikan saat ini adalah lemahnya proses pembelajaran, dimana mahasiswa kurang didorong untuk mengembangkan kemampuan 
berpikirnya, dan menjadikan sebuah pelajaran tersebut menjadi bermakna. Pembelajaran dikelas hanya diarahkan dalam menghafalkan informasi yang didapat dan kegiatan tersebut menimbulkan dorongan mahasiswa hanya fokus dalam mengingat dan menimbun informasi tanpa dituntut untuk memahami informasi yang diingat dan dihubungkan dalam kehidupan sehari hari (Anggereni, 2016). Penyebab lain dari kurang pahamnya mahasiswa terhadap pembelajaran yaitu pembelajaran jarak jauh yang dilakukan secara daring, hal ini karena pandemi COVID-19 yang mewabah di Indonesia pada Bulan Maret 2020. Pembelajaran daring yang dilakukan melalui aplikasi seperti zoom ataupun googlemeet membuat mahasiswa merasa bosan karena pembelajaran yang dilakukan terlalu monoton, intonasi yang kurang bervariasi, dan tidak dapat berinteraksi secara langsung dengan teman maupun pengajar (Pawicara dan Conilie, 2020). Salah satu penyebab rendahnya hasil belajar matakuliah fisika yaitu kurangnya pemanfaatan penggunaan teknologi dalam pembelajaran berbasis multimedia interaktif yang dapat dikembangkan sebagai model pembelajaran baru (Kurniawati dan Nita, 2018).

Media pembelajaran mampu membantu pendidik dalam menyampaikan materi saat proses belajar berlangsung. Penggunaan teknologi dalam penyampaian materi pun setidaknya perlu dikembangkan, apalagi dalam mata pelajaran fisika. Fisika menjadi suatu mata pelajaran yang tidak disukai oleh kebanyakan mahasiswa dikarenakan rumusnya yang beranekaragam serta konsep-konsepnya yang abstrak. Hal tersebut yang menjadi kesulitan dalam memahami konsep-konsep fisika yaitu proses fisika yang tidak dapat diamati secara langsung , akibatnya prose-proses fisika tersebut terlihat bersifat abstrak dan sukar untuk dipahami (Ika,2018). Hal ini menjadi sebuah tantangan tersendiri bagi guru fisika dalam membuat suatu media pembelajaran yang menarik agar mahasiswa menyukai fisika dan mampu memahami materi fisika yang disampaikan serta mengaplikasikannya dalam kehidupan sehari-hari. Ketika suatu media pembelajaran tersebut mampu menarik minat peserta didik dalam belajar, tentunya bukan hal yang sulit untuk mahasiswa memahami konsep pada materi yang disampaikan. Hal tersebut didukung dengan kemauan mahasiswa dalam mempelajari materi yang disusun secara menarik dalam media pembelajaran interaktif.

Media pembelajaran interaktif dapat mengeksplorasi wawasan mahasiswa dengan beberapa konten seperti animasi yang disinkronkan dengan materi yang disampaikan. Modul interaktif yang akan dikembangkan ini berisikan penjelasan materi, animasi, serta soal latihan yang bertujuan agar mahasiswa dapat mengasah kemampuannya selama mempelajari materi optik geometri menggunakan modul interaktif berbasis macromedia flash 8 (Cattelan et al, 2008). Arief (2020) menyatakan bahwa macromedia flash 8 merupakan software animasi yang biasa digunakan oleh para desainer guna menghasilkan desain yang professional. Macromedia flash 8 dengan segala kelebihannya antara lain mampu menyajikan hasil animasi yang menarik sehingga sangat membantu dalam pembelajaran fisika dan dengan menggunakan macromedia flash 8 ini mampu menggambarkan suatu materi yang bersifat abstrak dengan hasil animasi yang lebih mudah dicerna oleh mahasiswa. Doyan dkk (2013) menyatakan bahwa media pembelajaran berbantuan komputer dapat memuat materi fisika dengan disertai animasi statis maupun dinamis serta diperkaya dengan musik dengan tujuan untuk memudahkan siswa dalam memahami materi yang abstrak menjadi lebih nyata. Media pembelajaran berbasis macromedia flash juga dapat mempermudah guru dalam menyampaikan materi, sehingga peran guru sebagai fasilitator tidak perlu menyampaikan keseluruhan materi melalui ceramah. Meskipun guru berperan sebagai fasilitator, dalam menggunakan media pembelajaran berbasis macromedia flash guru juga perlu dibekali kemampuan yang cukup tentang penggunaan macromedia flash untuk membimbing siswa agar proses dalam pembelajaran dapat terlaksanan dengan baik (Matsun dkk, 2019).

Marisdo dkk (2020) dalam penelitiannya menyatakan bahwa dengan menggunakan media pembelajaran interaktif berbantuan macromedia flash mendapatkan respon yang positif dari mahasiswa sebesar $82,66 \%$ dengan kategori sangat baik sebab media pembelajaran interaktif mampu membantu mahasiswa dalam proses pemahaman konsepnya. Ali (2009) dalam penelitiannya menyatakan bahwa penggunaan modul interaktif pada mata kuliah medan elektromagnetik mendapatkan respon dengan nilai 3,23 pada skala likert dengan kategori sangat baik. Imansari (2016) dalam penelitiannya menyatakan bahwa penggunaan e-modul interaktif dalam materi kesehatan dan keselamatan kerja mampu meningkatkan hasil belajar mahasiswa serta mendapatkan respon yang baik mengenai media pembelajaran tersebut. Mutiara dkk (2019) dalam penelitiannya menyatakan bahwa media 
pembelajaran simulasi komputer menggunakan macromedia flash 8 layak digunakan dalam pembelajaran fisika di sekolah ditunjukkan dengan hasil penilaian sebesar $85,71 \%$ dengan kategori sangat layak. Sedangkan, Aththibby dan Barkah dalam penelitiannya menyatakan bahwa media berbasis animasi flash sangat layak digunakan dengan hasil $80,5 \%$ pada aspek teknis dengan kategori sangat baik dan $80,1 \%$ pada aspek konteks dengan kategori sangat baik juga. Berdasarkan beberapa penelitian yang telah dijabarkan, maka dapat disimpulkan bahwa penggunaan modul interaktif mampu mendukung proses pembelajaran guna memperoleh hasil yang diinginkan serta proses pembelajaran yang lebih kondusif.

Modul interaktif yang dikembangkan dikatakan berhasil selain dari hasil validasi juga dapat dilihat dari respon pengguna selama pembelajaran menggunakan modul tersebut. Respon berasal dari kata response yang berarti jawaban atau balasan atau tanggapan (Chaplin dkk, 2004). Kamus besar ilmu pengetahuan memberikan pernyataan bahwa respon merupakan suatu reaksi psikologis-metabolik terhadap suatu rangsangan, baik secara otomatis (reflek) ataupun secara terkendali (Save, 1997). Sesuai dengan uraian tersebut, dapat disimpulkan bahwa respon ialah suatu tanggapan terhadap sesuatu hal baik secara langsung maupun tidak langsung. Respon atau tanggapan yang diberikan oleh seseorang tentunya memiliki efek untuk orang itu sendiri maupun lingkungannya. Secara umum, tanggapan atau respon ialah suatu bentuk bayangan ataupun kesan dari apa yang dilihat dan diamati. Jika respon tersebut dilakukan ataupun diterima dalam keadaan tidak sadar maka disebut dengan respon/tanggapan laten, sedangkan jika respon tersebut dilakukan ataupun diterima dalam keadaan sadar maka disebut dengan respon/tanggapan actual.

Respon mahasiswa tentunya mendukung dalam kelancaran kegiatan pembelajaran fisika seperti pada materi optik geometri yang menggunakan modul interaktif berbasis macromedia flash 8. Optik geometri merupakan cabang ilmu fisika yang banyak mengandung konsep abstrak dan kompleks terkait fenomena pemantulan dan pembiasan cahaya. Materi ini memerlukan penjabaran melalui pendekatan diagram sinar secara geometri dan kaidah matematika (Thube dan Saligram, 2007). Materi optik geometri dianggap sulit bagi mahasiswa dikarenakan tidak pahamnya proses pembentukan bayangan dari awal dalam pelukisan bayangan pada cermin datar, cermin cekung, dan cermin cembung. Optik geometri merupakan ilmu yang mempelajari mengenai fenomena perambatan cahaya seperti pemantulan dan pembiasan. Cahaya akan mengalami pemantulan jika mengenai bidang batas dua medium yang berbeda. Pada pemantulan cahaya, cahaya yang jatuh pada bidang batas dua material akan mengalami pemantulan dengan sudut pantul sama dengan sudut datang. Hukum pemantulan cahaya yaitu:

$$
\boldsymbol{\theta}_{\boldsymbol{d}}=\boldsymbol{\theta}_{p}
$$

Dengan,

$\theta_{d}=$ Sudut datang cahaya

$\theta_{p}=$ Sudut pantul cahaya

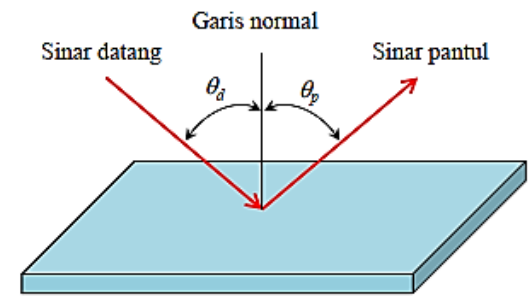

Gambar 1. Pada peristiwa pemantulan besarnya sudut datang sama dengan susut pantul

Perubahan arah rambat cahaya ketika berpindah dari suatu material ke material lain disebut pembiasan. Ada 2 syarat terjadinya pembiasan yaitu:

a. Perbedaan laju cahaya pada kedua medium

b. Arah datang cahaya tidak tegak lurus terhadap bidang pembatas kedua medium Hukum Snell tentang pembiasan cahaya yaitu:

$$
n_{1} \sin \theta_{d}=n_{2} \sin \theta_{b}
$$

Dimana,

$n_{1}=$ Indeks bias medium tempat cahaya datang $n_{2}=$ Indeks bias medium yang dituju cahaya $\theta_{d}=$ Sudut datang cahaya diukur dari arah tegak lurus bidang batas dua medium

$\theta_{b}=$ Sudut bias cahaya diukur dari arah tegak lurus bidang pembatas dua medium

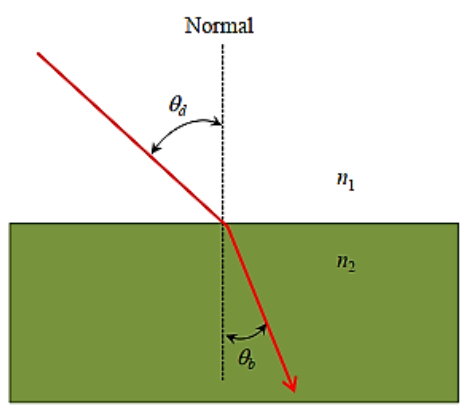

Gambar 2. Pembiasan cahaya pada bidang batas dua medium

(Mikrajuddin, 2017) 
Pada pembiasan cahaya, berkas cahaya yang datang dari medium yang kurang rapat ke medium yang lebih rapat dibiaskan mendekati garis normal, sedangkan berkas cahaya yang datang dari medium yang lebih rapat menuju medium yang kurang rapat akan dibiaskan menjauhi garis normal. Cermin dan lensa merupakan contoh dari alat optik yang prinsip kerjanya menerapkan peristiwa pembiasan dan pemantulan. Prinsip kerja dari cermin menerapkan peristiwa pemantulan sedangkan prinsip kerja dari lensa menerapkan peristiwa pembiasan (Viridi, 2014).

(Thube dan Saligram, 2007) dalam penelitian sebelumnya menyatakan bahwa mahasiswa sebenarnya memahami adanya pembantulan ataupun pembiasan pada cermin, hanya saja mahasiswa kesulitan untuk memberikan penjelasan saintifik terkait dengan proses bayangan tersebut dapat terbentuk. Optik geometri membutuhkan suatu media pembelajaran pendukung untuk mensimulasikan proses pemantulan ataupun pembiasan cahaya agar konsep atau penjelasan tersebut dapat dipahami oleh mahasiswa dan terkesan mudah.

Sesuai dengan uraian latar belakang di atas, penelitian ini akan membahas tentang "Pengembangan Modul Interaktif Pada Materi Optik Geometri". Adapun modul interaktif yang dikembangkan menggunakan macromedia flash 8 dilengkapi dengan materi, animasi, serta soal-soal latihan. Tujuannya adalah setelah mempelajari modul interaktif tersebut, mahasiswa lebih memahami konsep-konsep yang berlaku dalam materi tersebut.

\section{METODE PENELITIAN}

Pengembangan media pembelajaran fisika berbasis macromedia flash yang terintegrasi dengan Al-Quran menggunakan metode penelitian Research and Development (R\&D) dengan model pengembangan ADDIE. Model pengembangan ADDIE memiliki 5 tahapan dalam pelaksanaannya yaitu tahap Analysis (analisis), Design (perencanaan), Development(pengembangan), Implementation (pelaksanaan), dan Evaluation (evaluasi) sebagaimana ditunjukkan pada Gambar 3. Objek penelitian adalah mahasiswa program studi pendidikan fisika Universitas Jember yang menempuh mata kuliah Fisika Dasar III pada tahun akademik 2020/2021.

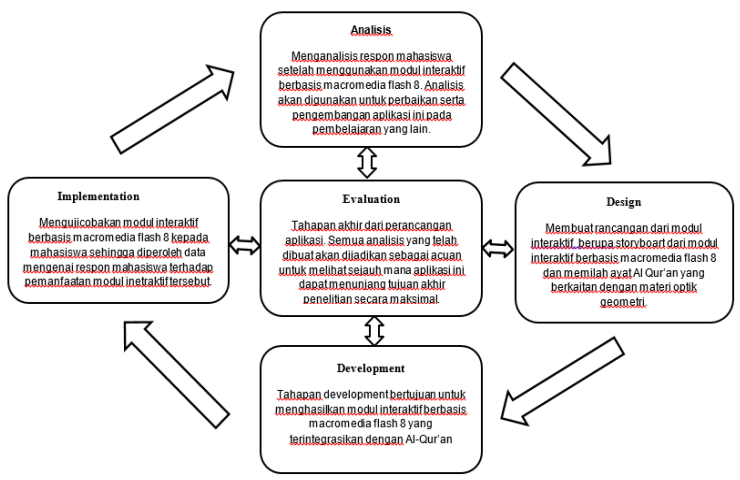

Gambar 3. Model Pengembangan ADDIE

\section{HASIL DAN PEMBAHASAN}

1. Desain Modul Interaktif berbasis Macromedia Flash 8

Hasil yang diperoleh dari penelitian ini berupa suatu produk media pembelajaran yaitu Modul Interaktif Berbasis Macromedia Flash 8 pada Materi Optik Geometri yang dapat digunakan oleh mahasiswa Fisika Dasar III sebagai media pembelajaran. Hasil akhir dari modul interaktif yang dikembangkan ini memiliki format .swf dan dapat dijalankan pada komputar atau laptop yang telah terinstal Macromedia Flash 8. Modul Interaktif Berbasis Macromedia Flash 8 ini dilengkapi dengan tombol-tombol interaktif yang membuat mahasiswa dapat berinteraksi dengan apa yang disajikan dalam media pembelajaran ini.

Modul Interaktif Berbasis Macromedia Flash 8 memiliki tampilan dengan menu dan sub menu yang dapat dipilih oleh mahasiswa dengan menekan tombol menu ataupun sub menu yang tersedia. Tampilan awal dari modul interaktif dimulai dengan sebuah intro berupa animasi loading. Gambar 4 merupakan bentuk tampilan awal dari Modul Interaktif Berbasis Macromedia Flash 8.

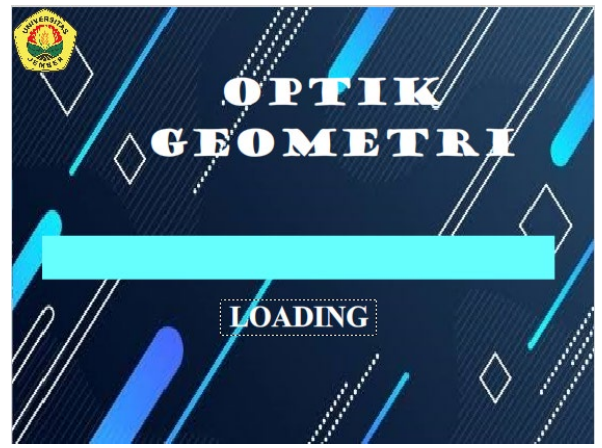

Gambar 4. Tampilan Awal Media

Menu utama pada modul berisikan tomboltombol menu yaitu CPMK, Tujuan Pembelajaran, Materi, Animasi, Ayat AlQur'an, Contoh Soal, Evaluasi, dan Tim Penelitian. Gambar 5 merupakan bentuk 
tampilan menu utama dari Modul Interaktif Berbasis Macromedia Flash 8.

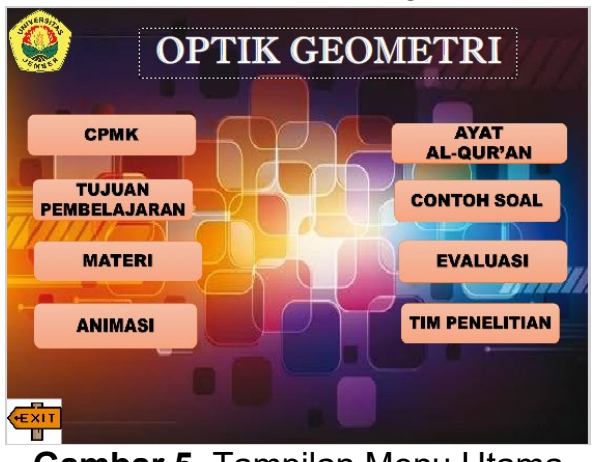

Pada menu CPMK berisi sub menu dari capaian pembelajaran mata kuliah yang harus dicapai dalam kegiatan pembelajaran mulai dari pengetahuan, keterampilan umum, keterampilan khusus, dan sikap. Gambar 6 merupakan bentuk tampilan menu CPMK dari Modul Interaktif Berbasis Macromedia Flash 8.

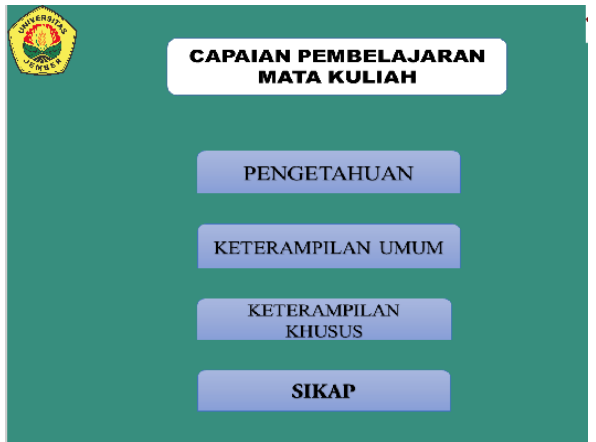

Gambar 6. Tampilan Menu CPMK

Menu tujuan menjelaskan mengenai tujuan pembelajaran yang ingin dicapai. Gambar 7 merupakan bentuk tampilan menu tujuan dari Modul Interaktif Berbasis Macromedia Flash 8.

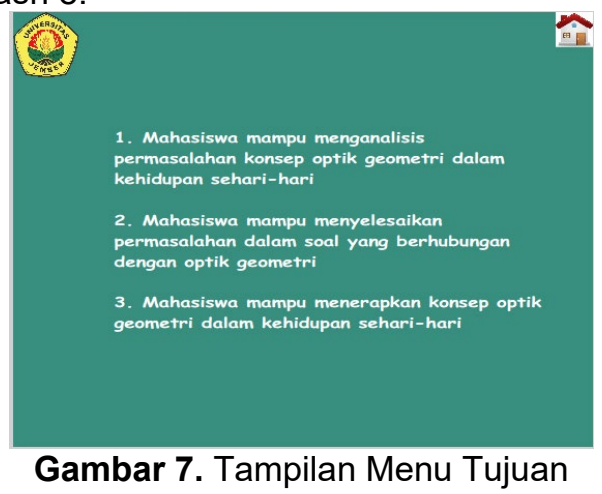

Menu materi berisikan penjelasan materi yang dipelajari mahasiswa. Tampilan awal dari menu materi berisi sub-sub materi dari optik geometri yang meliputi sifat-sifat cahaya, disperse, pemantulan, lensa, pembiasan, cermin, dan alat optik. Gambar
8 merupakan bentuk tampilan menu materi dari Modul Interaktif Berbasis Macromedia Flash 8.

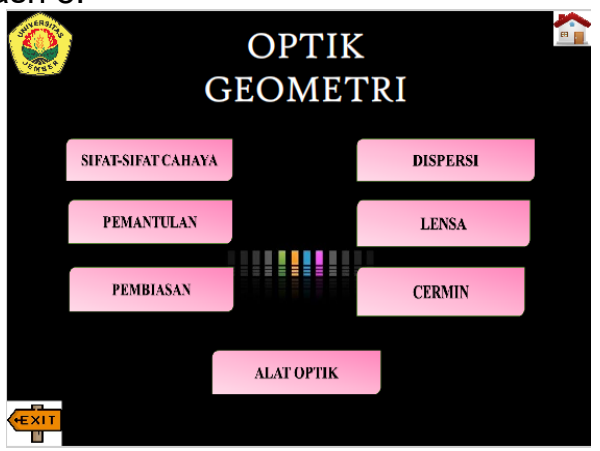

Gambar 8. Tampilan Menu Materi

Menu animasi pada modul terdiri atas tiga tombol animasi yaitu animasi 1 mengenai disperse, animasi 2 mengenai pembiasan, dan animasi 3 mengenai pemantulan pada cermin cekung. Salah satu animasi yang terdapat pada modul dapat dilihat pada Gambar 9.

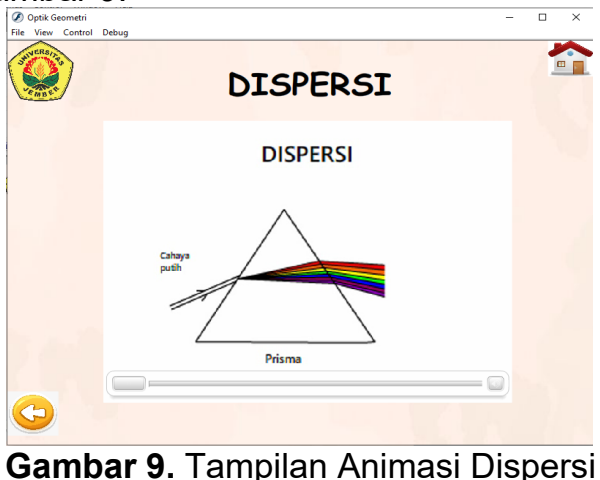

Menu ayat Al-Qur'an berisikan tentang ayat Al-Qur'an dan terjemahan dari ayat yang terkait dengan materi optik geometri yaitu surat An-Nur ayat 35. Gambar 10 merupakan bentuk tampilan menu ayat AlQur'an dari Modul Interaktif Berbasis Macromedia Flash 8.

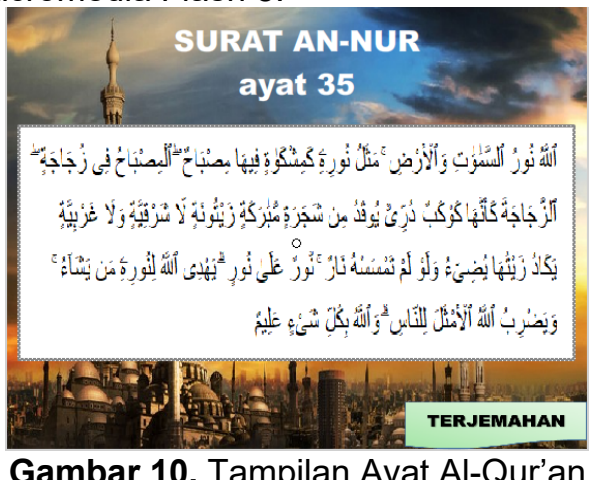

Pada menu contoh soal berisikan contoh soal optik geometri yang disertai dengan pembahasan masing-masing soal tersebut. Contoh soal dalam modul ini terdiri atas 4 
butir soal. Gambar 11 merupakan salah satu bentuk tampilan contoh soal dari Modul Interaktif Berbasis Macromedia Flash 8.

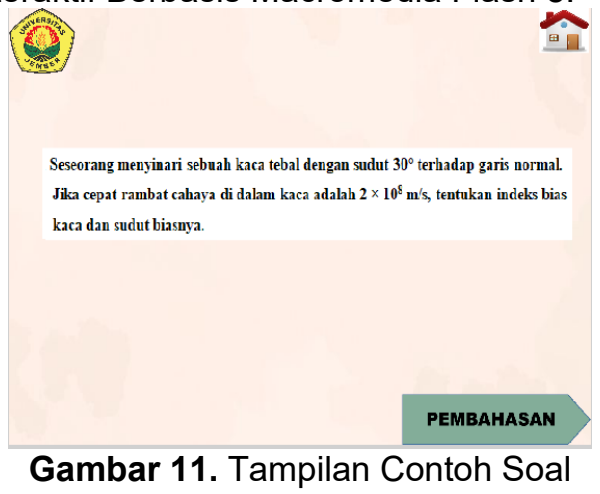

Menu latihan soal berisikan tentang soalsoal latihan mengenai optik geometri yang dapat dikerjakan oleh mahasiswa. Soal berjumlah 10 butir soal dalam bentuk pilihan ganda. Pada tampilan pertama menu latihan soal berisikan petunjuk dalam mengerjakan soal. Pada bagian terakhir dari menu latihan soal, secara otomatis dapat memunculkan skor yang didapatkan mahasiswa dari pengerjaan latihan soal. Jika skor atau nilai yang didapatkan masih rendah, mahasiswa dapat mengulangi mengerjakan soal kembali. Gambar 12 merupakan salah satu bentuk tampilan latihan soal dari Modul Interaktif Berbasis Macromedia Flash 8.

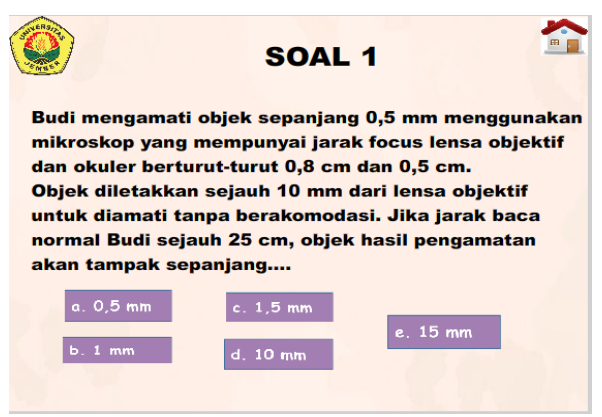

Gambar 12. Tampilan Latihan Soal

Pada bagian terakhir dari modul interaktif ini terdapat tim penelitian yang terlibat dalam pembuatan modul. Gambar 13 merupakan bentuk tampilan menu tim penelitian dari Modul Interaktif Berbasis Macromedia Flash 8.

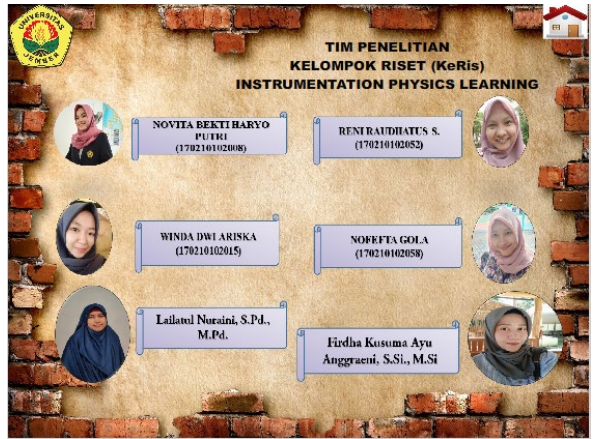

Gambar 13. Tampilam Tim Penelitian

\section{Hasil Respon Mahasiswa}

Angket yang disebarkan kepada mahasiswa yang menempuh mata kuliah Fisika Dasar III terdiri atas 6 pernyataan positif dan 5 pernyataan negatif. Pernyataan positif memiliki skor 4 untuk respon sangat setuju, skor 3 untuk respon setuju, skor 2 untuk respon tidak setuju, dan skor 1 untuk respon sangat tidak setuju. Sedangkan untuk pernyataan negatif memiliki skor 4 untuk respon sangat tidak setuju, skor 3 untuk respon tidak setuju, skor 2 untuk respon setuju, dan skor 1 untuk respon sangat tidak setuju. Berdasarkan angket yang telah disebarkan kepada mahasiswa yang menempuh mata kuliah Fisika Dasar 3 didapatkan hasil sebagai berikut:

Pernyataan pertama merupakan suatu pernyataan positif dengan pernyataan "Saya menyukai mata kuliah fisika dasar III khususnya pada materi optik geometri dengan penggunaan modul interaktif berbasis macromedia flash 8". Hasil respon mahasiswa terhadap pernyataan pertama dapat dilihat sebagaimana ditunjukkan pada Gambar 14:

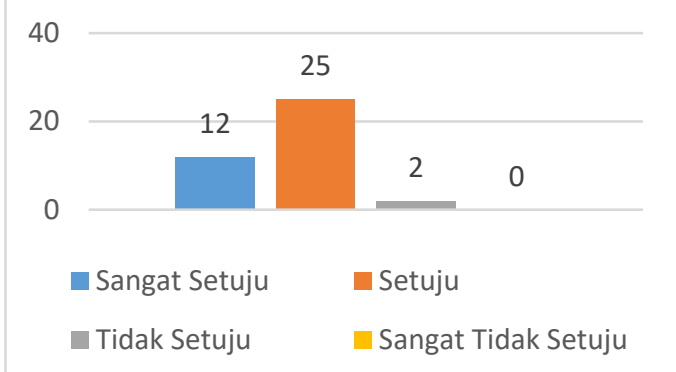

Gambar 14. Diagaram Respon Pernyataan Pertama

Berdasarkan Gambar 14, untuk pernyataan positif didapatkan 12 mahasiswa merespon sangat setuju, 25 mahasiswa merespon setuju, dan 2 mahasiswa merespon tidak setuju. Hal ini dapat disimpulkan bahwa mayoritas mahasiswa yang menempuh mata kuliah Fisika Dasar III menyukai pembelajaran menggunakan modul interaktif pada materi 
optik geometri. Persentase hasil respon pernyataan pertama sebesar $81,4 \%$.

Pernyataan kedua merupakan pernyataan negatif dengan pernyataan "Saya kurang menyukai mata kuliah Fisika Dasar III setelah belajar dengan menggunakan modul interaktif berbasis macromedia flash 8". Hasil respon mahasiswa terhadap pernyataan kedua dapat dilihat sebagaimana ditunjukkan pada Gambar 15:

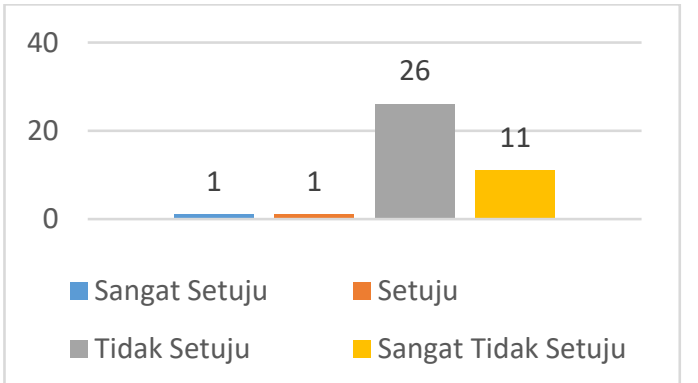

Gambar 15. Diagaram Respon Pernyataan Kedua

Berdasarkan Gambar 15, dapat dijabarkan jika 1 mahasiswa merespon sangat setuju, 1 mahasiswa merespon setuju, 26 mahasiswa merespon tidak setuju, dan 11 mahasiswa merespon sangat tidak setuju. Hal ini dapat disimpulkan bahwa mayoritas mahasiswa menyukai pembelajaran Fisika Dasar III setelah menggunakan modul interaktif. Persentase hasil respon pernyataan kedua sebesar $80,1 \%$.

Pernyataan ketiga merupakan pernyataan positif dengan pernyataan "Saya menyukai cara belajar menggunakan modul interaktif berbasis macromedia flash 8 pada materi optik geometri". Hasil respon mahasiswa terhadap pernyataan ketiga dapat dilihat sebagaimana ditunjukkan pada Gambar 16:

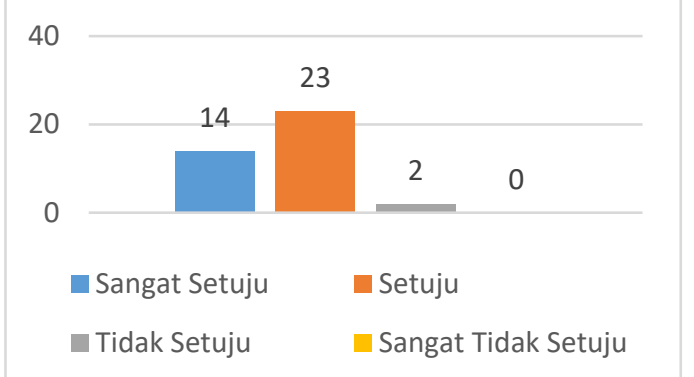

Gambar 16. Diagaram Respon Pernyataan Ketiga

Berdasarkan Gambar 16, dapat dinyatakan bahwa 14 mahasiswa merespon sangat setuju, 23 mahasiswa merespon setuju, dan 2 mahasiswa merespon tidak setuju. Hal ini dapat disimpulkan jika mayoritas mahasiswa menyukai pembelajaran menggunakan modul interaktif berbasis macromedia flash 8 . Persentase hasil respon pernyataan ketiga sebesar $82,7 \%$.

Pernyataan keempat merupakan pernyataan negatif dengan pernyataan "Saya kurang menyukai cara belajar dengan menggunakan modul interaktif berbasis macromedia flash 8 pada materi optik geometri". Hasil respon mahasiswa terhadap pernyataan keempat dapat dilihat sebagaimana ditunjukkan pada Gambar 17.

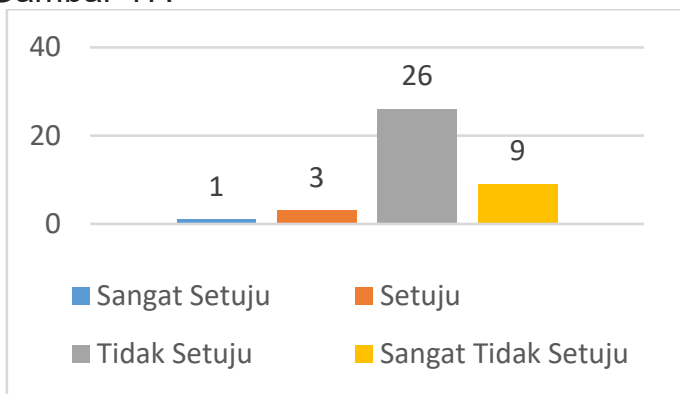

Gambar 17. Diagaram Respon Pernyataan Keempat

Berdasarkan Gambar 17 dapat dijabarkan bahwa 1 mahasiswa merespon sangat setuju, 3 mahasiswa merespon setuju, 26 mahasiswa merespon tidak setuju, dan 9 mahasiswa merespon sangat tidak setuju. Sehingga dapat disimpulkan bahwa mayoritas mahasiswa tidak setuju jika pembelajaran menggunakan modul interaktif berbasis macromedia flash 8 tidak menyenangkan. Persentase hasil respon pernyataan keempat sebesar $77,6 \%$.

Pernyataan kelima merupakan pernyataan positif dengan pernyataan "Dengan penggunaan modul interaktif berbasis macromedia flash 8 dapat membuat saya lebih mudah memahami materi optik geometri". Hasil respon mahasiswa terhadap pernyataan kelima dapat dilihat sebagaimana ditunjukkan pada Gambar 18.

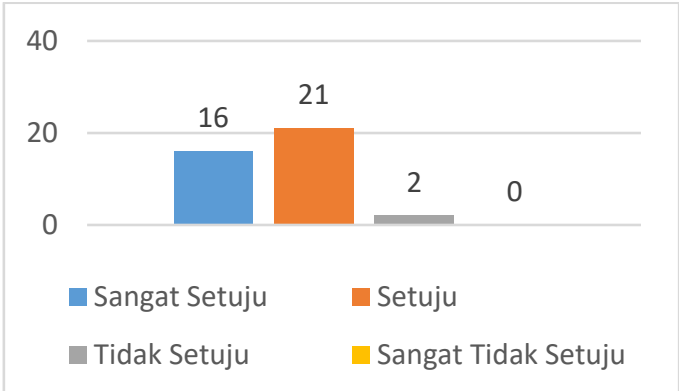

Gambar 18. Diagaram Respon Pernyataan Kelima

Berdasarkan Gambar 18 dapat dijabarkan bahwa 16 mahasiswa merespon sangat 
setuju, 21 mahasiswa merespon setuju, dan 2 mahasiswa merespon tidak setuju. Hal ini dapat disimpulkan bahwa mayoritas mahasiswa merasa lebih mudah memahami materi optik geometri ketika menggunakan modul interaktif berbasis macromedia flash 8 . Persentase hasil respon pernyataan kelima sebesar $84,0 \%$.

Pernyataan keenam merupakan pernyataan negatif dengan pernyataan "Modul interaktif berbasis macromedia flash 8 ini membuat saya semakin kesulitan memahami materi optik geometri". Hasil respon mahasiswa terhadap pernyataan keenam dapat dilihat sebagaimana ditunjukkan pada gambar 19.

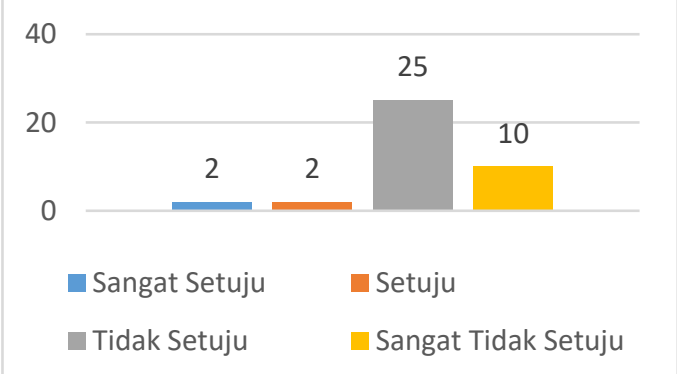

Gambar 19. Diagaram Respon Pernyataan Keenam

Berdasarkan Gambar 19 dapat dijabarkan bahwa 2 mahasiswa merespon sangat setuju, 2 mahasiswa merespon setuju, 25 mahasiswa merespon tidak setuju, dan 10 mahasiswa merespon sangat tidak setuju. Hal ini dapat disimpulkan bahwa mayoritas mahasiswa tidak setuju jika pembelajaran menggunakan modul interaktif berbasis macromedia flash 8 menjadikan mahasiswa kesulitan dalam memahami materi. Persentase hasil respon pernyataan keenam sebesar $77,6 \%$.

Pernyataan ketujuh merupakan pernyataan positif dengan pernyataan "Saya menjadi lebih aktif dengan adanya modul interaktif berbasis macromedia flash 8 dalam pembelajaran pada materi optik geometri". Hasil respon mahasiswa terhadap pernyataan ketujuh dapat dilihat sebagaimana ditunjukkan pada Gambar 20.

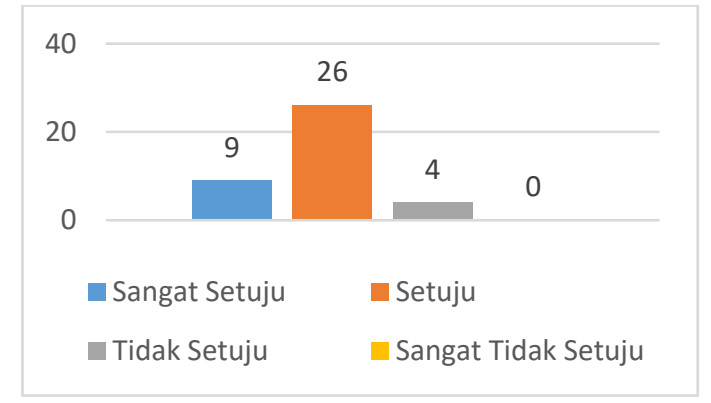

Gambar 20. Diagaram Respon Pernyataan Ketujuh

Berdasarkan Gambar 20 dapat dijabarkan bahwa 9 mahasiswa merespon sangat setuju, 26 mahasiswa merespon setuju, dan 4 mahasiswa merespon tidak setuju. Hal ini dapat disimpulkan bahwa mayoritas mahasiswa merasa lebih aktif dalam pembelajaran Fisika Dasar III pada materi optik geometri ketika menggunakan modul interaktif berbasis macromedia flash 8 . Persentase hasil respon pernyataan ketujuh sebesar $78,2 \%$.

Pernyataan kedelapan merupakan pernyataan negatif dengan pernyataannya "Dengan penggunaan modul interaktif berbasis macromedia flash 8 dapat membuat saya kesulitan dalam memecahkan masalah dan menjawab soal pada materi optik geometri". Hasil respon mahasiswa terhadap pernyataan kedelapan dapat dilihat sebagaimana ditunjukkan pada Gambar 21.

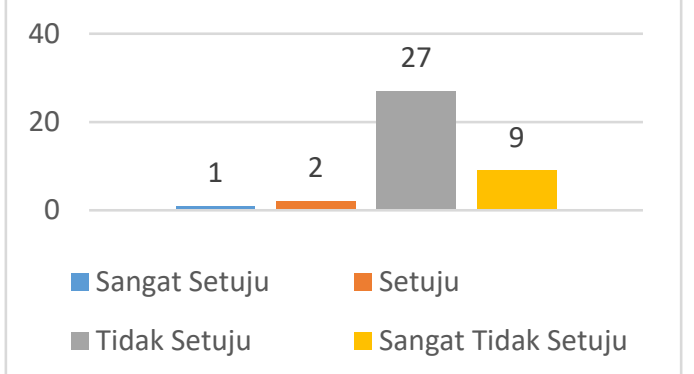

Gambar 21. Diagaram Respon Pernyataan Kedelapan

Berdasarkan Gambar 21 dapat dijabarkan bahwa 1 mahasiswa merespon sangat setuju, 2 mahasiswa merespon setuju, 27 mahasiswa merespon tidak setuju, dan 9 mahasiswa merespon sangat tidak setuju. Hal ini dapat disimpulkan bahwa mayoritas mahasiswa tidak setuju jika pembelajaran menggunakan modul interaktif berbasis macromedia flash 8 menjadikan mahasiswa kesulitan dalam memecahkan suatu permasalahan dan dalam menjawab soal. Persentase hasil respon pernyataan kedelapan sebesar $78,2 \%$.

Pernyataan kesembilan merupakan pernyataan positif dengan pernyataannya "Saya tertarik pada tampilan (cover, tulisan, gambar dan animasi) modul interaktif berbasis macromedia flash 8 ini". Hasil respon mahasiswa terhadap pernyataan kesembilann dapat dilihat sebagaimana ditunjukkan pada Gambar 22. 


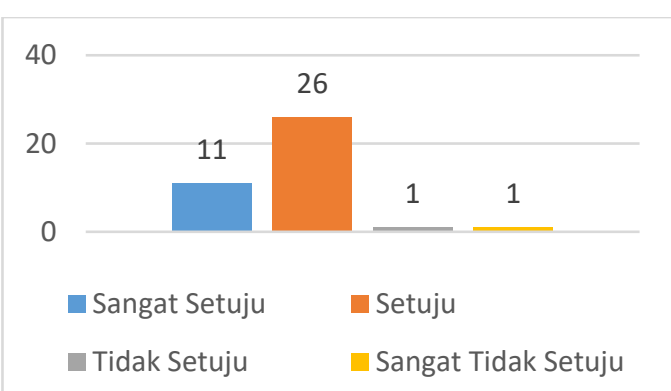

Gambar 22. Diagaram Respon Pernyataan Kesembilan

Berdasarkan Gambar 22 dapat dijabarkan bahwa 11 mahasiswa merespon sangat setuju, 26 mahasiswa merespon setuju, 1 mahasiswa merespon tidak setuju, dan 1 mahasiswa merespon sangat tidak setuju. Hal ini dapat disimpulkan bahwa mayoritas mahasiswa tertarik dengan tampilan awal (cover) modul interaktif berbasis macromedia flash 8 tersebut. Persentase hasil respon pernyataan kesembilan sebesar $80,1 \%$.

Pernyataan kesepuluh merupakan pernyataan negatif dengan pernyataannya "Desain modul interaktif berbasis macromedia flash 8 membuat saya terganggu dalam memahami materi optik geometri". Hasil respon mahasiswa terhadap pernyataan kesepuluh dapat dilihat sebagaimana ditunjukkan pada Gambar 23.

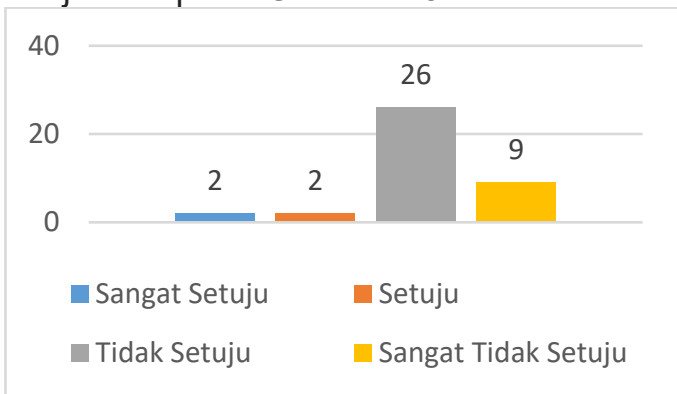

Gambar 23. Diagaram Respon Pernyataan Kesepuluh

Berdasarkan Gambar 23 dapat dijabarkan bahwa 2 mahasiswa merespon sangat setuju, 2 mahasiswa merespon setuju, 26 mahasiswa merespon tidak setuju, dan 9 mahasiswa merespon sangat tidak setuju. Hal ini dapat disimpulkan bahwa mayoritas mahasiswa tidak merasa terganggu dengan desain modul interaktif berbasis macromedia flash 8 tersebut. Persentase hasil respon pernyataan kesepuluh sebesar $76,9 \%$.

Pernyataan kesebelas merupakan pernyataan positif dengan pernyataannya "Dengan modul interaktif berbasis macromedia flash 8 ini membuat saya lebih mudah memahami pengaplikasian konsep optik geometri dalam kehidupan sehari hari". Hasil respon mahasiswa terhadap pernyataan kesebelas dapat dilihat sebagaimana ditunjukkan pada Gambar 24.

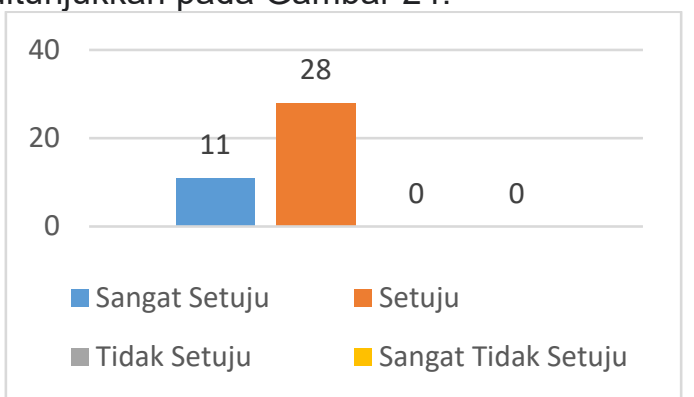

Gambar 24. Diagaram Respon Pernyataan Kesebelas

Berdasarkan Gambar 24 dapat dijabarkan bahwa 11 mahasiswa merespon sangat setuju dan 28 mahasiswa merespon setuju. Hal ini dapat disimpulkan bahwa mayoritas mahasiswa tidak merasa kesulitan dalam memahami pengaplikasian konsep optik geometri dalam kehidupan sehari-hari setelah melakukan pembelajaran menggunakan modul interaktif berbasis macromedia flash 8 tersebut. Persentase hasil respon pernyataan kesebelas sebesar $82,1 \%$.

Sesuai dengan uraian di atas, dapat disimpulkan hasil persentase dari pernyataan di atas dapat dilihat pada table 3 berikut ini:

Tabel 3. Persentase total pernyataan respon

\begin{tabular}{|c|c|c|c|}
\hline $\begin{array}{l}\mathbf{N} \\
\mathbf{0}\end{array}$ & Pernyataan & $\begin{array}{c}\text { Persenta } \\
\text { se }\end{array}$ & $\begin{array}{c}\text { Total } \\
\text { Persenta } \\
\text { se }\end{array}$ \\
\hline 1 & $\begin{array}{l}\text { Saya } \\
\text { menyukai } \\
\text { mata kuliah } \\
\text { fisika dasar } \\
\text { III } \\
\text { khususnya } \\
\text { pada materi } \\
\text { optik } \\
\text { geometri } \\
\text { dengan } \\
\text { penggunaan } \\
\text { modul } \\
\text { interaktif } \\
\text { berbasis } \\
\text { macromedia } \\
\text { flash } 8\end{array}$ & $81.40 \%$ & $80.75 \%$ \\
\hline & $\begin{array}{l}\text { Saya kurang } \\
\text { menyukai } \\
\text { mata kuliah }\end{array}$ & $80.10 \%$ & \\
\hline
\end{tabular}


Fisika Dasar

III setelah

belajar

dengan

menggunaka

$\mathrm{n}$ modul

interaktif

berbasis

macromedia

flash 8

\begin{tabular}{|c|c|c|c|}
\hline \multirow[b]{2}{*}{2} & $\begin{array}{l}\text { Saya } \\
\text { menyukai } \\
\text { cara belajar } \\
\text { menggunaka } \\
\text { n modul } \\
\text { interaktif } \\
\text { berbasis } \\
\text { macromedia } \\
\text { flash } 8 \text { pada } \\
\text { materi optik } \\
\text { geometri }\end{array}$ & $82.70 \%$ & \multirow[b]{2}{*}{$80.15 \%$} \\
\hline & $\begin{array}{l}\text { Saya kurang } \\
\text { menyukai } \\
\text { cara belajar } \\
\text { dengan } \\
\text { menggunaka } \\
\text { n modul } \\
\text { interaktif } \\
\text { berbasis } \\
\text { macromedia } \\
\text { flash } 8 \text { pada } \\
\text { materi optik } \\
\text { geometri }\end{array}$ & $77.60 \%$ & \\
\hline \multirow[t]{2}{*}{3} & $\begin{array}{l}\text { Dengan } \\
\text { penggunaan } \\
\text { modul } \\
\text { interaktif } \\
\text { berbasis } \\
\text { macromedia } \\
\text { flash } 8 \text { dapat } \\
\text { membuat } \\
\text { saya lebih } \\
\text { mudah } \\
\text { memahami } \\
\text { materi optik } \\
\text { geometri }\end{array}$ & $84.00 \%$ & \multirow[t]{2}{*}{$80.80 \%$} \\
\hline & $\begin{array}{l}\text { Modul } \\
\text { interaktif } \\
\text { berbasis } \\
\text { macromedia } \\
\text { flash } 8 \text { ini } \\
\text { membuat } \\
\text { saya }\end{array}$ & $77.60 \%$ & \\
\hline
\end{tabular}

semakin

kesulitan

memahami

materi optik

geometri

\section{Saya tertarik}

pada

tampilan

(cover,

tulisan,

gambar dan

animasi)

$80.10 \%$

modul

interaktif

berbasis

macromedia

flash 8 ini

4

Desain

$78.50 \%$

modul

interaktif

berbasis

macromedia

flash 8

membuat

$76.90 \%$

saya

terganggu

dalam

memahami

materi optik

geometri

\section{Dengan}

modul

interaktif

berbasis

macromedia

flash 8 ini

membuat

saya lebih

mudah

$82.10 \%$

memahami

pengaplikasi

5 an konsep

optik

geometri

dalam

kehidupan

sehari hari

Dengan

penggunaan

modul

interaktif

berbasis

macromedia 
flash 8 dapat

membuat

saya

kesulitan

dalam

memecahka

n masalah

dan

menjawab

soal pada

materi optik

geometri

\section{Saya}

menjadi

lebih aktif

dengan

adanya

modul

interaktif

berbasis

$78.20 \%$

$78.20 \%$

macromedia

flash 8

dalam

pembelajara

$\mathrm{n}$ pada

materi optik

6 geometri
Sesuai dengan pemberian bobot tiap respon mahasiswa berdasarkan masing-masing pernyataan, diperoleh hasil persentase sebesar 79,8\%. Jika disesuaikan dengan tabel 2 mengenai kriteria persentase respon mahasiswa, maka modul interaktif berbasis macromedia flash 8 pada materi optik geometri dikategorikan "baik" yang artinya dapat diterima dan digunakan dengan oleh mahasiswa yang menempuh mata kuliah Fisika Dasar III.

\section{PEMBAHASAN}

Penelitian ini dilakukan untuk mengembangkan bahan ajar (modul) yang dikemas lebih menarik dengan menggunakan software macromedia flash 8 pada materi optik geometri terintegrasi dengan ayat AI-Qur'an guna menunjang proses pembelajaran daring (online) secara mandiri oleh mahasiswa yang menempuh mata kuliah Fisika Dasar III. Setelah menggunakan modul interaktif ini diharapkan ada respon positif yang diberikan oleh mahasiswa terkait pemahaman materi optik geometri.

Langkah awal dari pengembangan modul ini yakni menganalisis masalah terlebih dahulu mengenai pembelajaran Fisika Dasar secara online. Kendala yang ditemukan yakni kurangnya media pembelajaran yang bersifat digital yang dapat digunakan secara mandiri oleh mahasiswa. Hal selanjutnya yang harus dilakukan setelah mengetahui permasalahan yakni mencari software yang sesuai untuk mengembangkan media pembelajaran berbasis digital yang mampu digunakan secara mandiri dan memiliki akses yang mudah. Proses pembuatan modul ini melalui tahap revisi terlebih dahulu hingga benar-benar layak digunakan. Setelah melalui proses revisi, modul interaktif ini diaplikasikan atau digunakan oleh mahasiswa yang menempuh mata kuliah Fisika Dasar III. Langkah selanjutnya yakni menyebarkan angket respon kepada mahasiswa yang menempuh mata kuliah Fisika Dasar III guna respon mahasiswa setelah menggunakan modul interaktif berbasis macromedia flash 8 selama proses pembelajaran materi optik geometri.

Modul interaktif berbasis macromedia

flash 8 merupakan suatu bahan bajar yang memanfaatkan teknologi dalam pengemasannya. Hal ini bertujuan agar materi yang disampaikan menarik minat mahasiswa untuk mempelajari dan memahami konsepkonsep materi yang dituliskan di dalam modul tersebut. Penggunaan macromedia flash 8 dirasa mampu memberikan tampilan yang menarik sehingga saat proses belajar berlangsung, mahasiswa tidak merasa bosan dengan tampilan atau desain dari modul interaktif berbasis macromedia flash 8 . Modul interaktif berbasis macromedia flash 8 pada materi optik geometri ini didesain sedemikian rupa dengan berisikan materi, animasi pendukung, ayat Al-Qur'an yang relevan, contoh soal, dan latihan soal guna membantu mahasiswa dalam proses pembelajarannya.

Penggunaan modul interaktif berbasis macromedia flash 8 tak hanya di tingkat mahasiswa saja melainkan bisa diterapkan pada jenjang sekolah dasar hingga sekolah menengah atas. Beberapa penelitian mengenai pendeskripsian respon terhadap hasil pengembangan media pembelajaran interkatif yakni penelitian Marisdo dkk (2020) menyatakan bahwa dengan menggunakan media pembelajaran interaktif berbantuan macromedia flash mendapatkan respon yang positif dari mahasiswa sebesar $82,66 \%$ dengan kategori sangat baik sebab media pembelajaran interaktif mampu membantu mahasiswa dalam proses pemahaman konsepnya. Ali (2009) dalam penelitiannya menyatakan bahwa penggunaan modul interaktif pada mata kuliah medan elektromagnetik mendapatkan respon dengan nilai 3,23 pada skala likert dengan kategori sangat baik. Imansari (2016) dalam 
penelitiannya menyatakan bahwa penggunaan e-modul interaktif dalam materi kesehatan dan keselamatan kerja mampu meningkatkan hasil belajar mahasiswa serta mendapatkan respon yang baik mengenai media pembelajaran tersebut. Mutiara dkk (2019) dalam penelitiannya menyatakan bahwa media pembelajaran simulasi komputer menggunakan macromedia flash 8 layak digunakan dalam pembelajaran fisika di sekolah ditunjukkan dengan hasil penilaian sebesar $85,71 \%$ dengan kategori sangat layak. Sedangkan, Aththibby dan Barkah dalam penelitiannya menyatakan bahwa media berbasis animasi flash sangat layak digunakan dengan hasil $80,5 \%$ pada aspek teknis dengan kategori sangat baik dan $80,1 \%$ pada aspek konteks dengan kategori sangat baik juga.

Berdasarkan hasil persentase ratarata respon mahasiswa terhadap hasil pengembangan modul interaktif berbasis macromeda flash 8 diperoleh persentase $79,8 \%$ yang termasuk ke dalam kategori "baik". Kategori baik yang dimaksud yakni, mahasiswa menerima modul interkatif berbasis macromedia flash 8 dalam proses pembelajaran pada materi optik geometri. Tak hanya itu, dengan kategori baik ini berarti modul ini dapat membantu mahasiswa dalam memahami materi optik geometri dan mengasah kemampuannya melalui soal-soal latihan yang telah disediakan.

Saran yang diberikan pengguna jika dianalisis dari respon yang diberikan yakni desain modul yang perlu dibuat lebih menarik lagi. Tak hanya itu, penjelasan mengenai pengaplikasian konsep dalam kehidupan sehari-hari juga perlu ditambahkan guna menambah wawasan mahasiswa terhadap materi optik geometri yang memerlukan penjelasan lebih detail terkait konsep-konsep yang berlaku. Hal ini bertujuan agar media pembelajaran yang digunakan dapat secara maksimal membantu proses pembelajaran jarak jauh.

\section{SIMPULAN DAN SARAN \\ Simpulan}

Sesuai dengan penelitian yang telah dilakukan bahwa modul interaktif berbasis macromedia flash 8 pada materi optik geometri memperoleh respon yang baik dari mahasiswa yang menempuh mata kuliah Fisika Dasar III dengan persentase hasil respon $79,8 \%$ yang termasuk ke dalam kategori baik.

\section{Saran}

Sesuai dengan penelitian yang telah dilaksanakan, maka peneliti memberikan beberapa saran untuk penelitian selanjutnya yakni: 1). Modul interaktif berbasis macromedia flash 8 mendapat respon yang positif dalam proses pembelajaran, namun desain modul yang dirasa kurang menarik perlu adanya revisi serta penjelasan yang terkait pengaplikasian dalam kehidupan sehari-hari pelu ditambahkan, 2). Modul interaktif berbasis macromedia flash 8 dapat dikembangkan juga untuk materi fisika yang lain.

\section{UCAPAN TERIMAKASIH}

Ucapan terimakasih disampaikan kepada Lembaga Penelitian dan Pengabdian kepada Masyarakat (LP2M) Universitas Jember serta Kelompok Riset Instrumentation Physics Learning Program Studi Pendidikan Fisika yang telah mendukung terlaksananya kegiatan penelitian ini.

\section{DAFTAR PUSTAKA}

Abdullah, M. 2017. Fisika Dasar II. Bandung: Institut Teknologi Bandung

Ali, M. (2009). Pengembangan Media Pembelajaran Interaktif Mata Kuliah Medan Elektromagnetik. Vol. 5 No. http://journal.uny.ac.id.

Anggereni, S. 2016. Efektivitas Pembelajaran Menggunakan Media Pembelajaran Macromedia Flash dalam Meningkatkan Pemahaman Konsep Fisika Materi Hukum Newton. Jurnal Biotek. 4(2):335

Arief. (2010). Media Pendidikan. Bandung: PT. Rajagrafindo Persada.

Cattelan, R. G., Teixeira, C., Goularte, R., \& Pimentel, M. D. G. . (2008). Watch-andcomment as a paradigm toward ubiquitous interactive video editing. ACM Trans. Multimedia Comput. Commun., Appl, 4(4).

Chaplin, J. P. (2004). Kamus Lengkap Psikologi, cet. Ke-9. Jakarta: PT. Raja Grafindo Persada.

Doyan, A., Gunawan, \& Azmi Syukroyanti. (2013). Pengembangan Media Animasi Berbasis Macromedia Flash Pada Pelajaran Fisika Alat Optik. Jurnal IImiah Pendidikan Fisika "Lensa". Vol.1(2).

Ika, Y. E. 2018. Penerapan Macromedia Flash Untuk Meningkatkan Pemahaman Konsep Fisika Siswa di SMA. Scientifical Colloquia. 1(2):31.

Imansari, N. (2016). Pengembangan Modul Pembelajaran Mata Kuliah Teori Medan. Jurnal Pendidikan Teknik Elektro, Vol.1(2),.

Jhon, M. E. dan H. S. (2003). Kamus Bahasa Inggris-Indonesia, cet. Ke-27. Jakarta: 
PT. Gramedia.

Kurniawati, Inung, D., \& Sekreningsih Nita. 2018. Media Pembelajaran Berbasis Multimedia Interaktif untuk Meningkatkan Pemahaman Konsep Mahasiswa. Journal of Computer and Information Technology. 1(2):68.

Mardapi, D. (2008). Teknik Penyusunan Instrumen Tes dan Non Tes. Yogyakarta: Mitra Cendikia Prss.

Marisda, D. H. \& R. (2020). Model Pembelajaran Konseptual Interaktif dalam Mata Kuliah IPA Terpadu, dalam Prosiding Simposium Fisika Nasional (SFN) -XXXI Inovasi Fisika. Physical Society of Indonesia SUMUT. Medan, 21-22 September 2020.

Matsun, Handy D., \& Lia Fitriyanti. (2019). Pengembangan Media Pembelajaran Fisika Berbasis Macromedia Flash Topik Bahasan Pesawat Sederhana Kelas VIII SMP. Jurnal Pendidikan Matematika dan IPA. Vol.10(1).

Mutiara, N., Andri S., \& Asep S. (2019). Pengembangan Media Pembelajaran Fisika Simulasi Komputer Menggunakan Macromedia Flash 8.0 Pada Materi Alat Optik. Prosiding Seminar Nasional Pendidikan Fisika Untirta. Vol.2(1).

Pawicara, Ruci \& Maharan,i C. 2020. Analisis Pembelajaran Daring Terhadap Kejenuhan Belajar Mahasiswa Tadris Biologi IAIN Jember di Tengah Pandemi Covid-19. Alveoli:Jurnal Pendidikan Biologi. 1(1):30.

Putri, R. S. (2019). Pengembangan Media Pembelajaran Berbasis Android Pada Materi Sistem Koloid Di Sma Negeri 2 Banda Aceh. Universitas Islam Negeri Ar-Raniry Banda Aceh, 108. https://repository.arraniry.ac.id/id/eprint/10021/

Save D. Dagun. (2005). Kamus Besar ilmu Pengetahuan. Jakarta: Lembaga Pengkajian dan Kebudayaan Nusantara.

Sugiono. (2016). Metode Penelitan Kuantitatif, kualitatif dan R\&D. Bandung: Alfabeta.

Suharsimi, A. (2006). Prosedur Penelitian Suatu Pendekatan Praktik. Jakarta: Rineka Cipta.

Thube, S. G., \& Shaligram, A. D. (2007). Effectiveness of Computer Assisted Teaching of Geometrical Optics at Undergraduate Level. Physics Education, 263-272.

Viridi, S., \& Novitrian. (2014). Cahaya dan Optik: Pemantulan-Cermin dan Pembiasan-Lensa. Pelatihan
Penguatan Kompetensi Guru OSN Tingkat SMP \& SMA Se-Aceh Batch III, 1(4), 1-7. https://doi.org/10.13140/2.1.1383.1047 